ROCZNIK ADMINISTRACJI PUBLICZNEJ 2021 (7)

ARTYKUŁY / ARTICLES

Prawo i administracja Unii Europejskiej

Law and Administration of the European Union

\title{
Niespójność wersji językowych aktu prawa UE jako podstawa do wystąpienia z pytaniem prejudycjalnym
}

\section{Wstęp}

Omawiane zagadnienie ma charakter prawno-lingwistyczny i wiąże się ze szczególnym rodzajem trudności interpretacyjnych, jakie mogą pojawić się w przypadku dekodowania normy prawnej z tekstu aktu prawnego, a mianowicie takich, które wynikają z rozbieżności pomiędzy poszczególnymi wersjami językowymi tego samego aktu prawnego. Tego rodzaju trudności interpretacyjne, $\mathrm{z}$ racji swej natury nie mogą pojawić się w toku wykładni aktów prawa krajowego i są swoiste dla aktów prawa Unii Europejskiej ${ }^{2}$. Nie można ich zatem rozstrzygnąć za pomocą tradycyjnych reguł interpretacyjnych, co z kolei stawia podmiot dokonujący wykładni (w szczególności sąd rozpatrujący daną sprawę) w obliczu pytania, jak należy postąpić w przypadku ich wystąpienia (w przypadku sądu w rozumieniu art.267 TFUE rozważenia wymaga zasadność wystąpienia z pytaniem prejudycjalnym). Równie istotną kwestią są pytania: w jakich okolicznościach sąd powinien sięgać do różnych wersji językowych danego aktu oraz ile wersji powinien wziąć pod uwagę? Próba odpowiedzi na te pytania zostanie przedstawiona w drodze analizy odesłań prejudycjalnych, w których właśnie tego typu problemy interpretacyjne skutkowały przedstawieniem pytania prejudycjalnego Trybunałowi Sprawiedliwości Unii Europejskiej. Omówienie przykładów należy jednak poprzedzić uwagami ogólnymi - dotyczącymi wielojęzycznego charakteru systemu prawa Unii Europejskiej.

1 Radosław Radosławski, Wicedyrektor Biura Legislacyjnego, Kancelaria Sejmu RP.

2 Trudności interpretacyjne tego typu mogą pojawić się także w procesie wykładni umów międzynarodowych - por. art. 33 Konwencji Wiedeńskiej o Prawie Traktatów (Dz. U. z 1990 r. Nr 74, poz. 439). 


\section{Zasada jednakowej autentyczności wszystkich wersji językowych aktów prawa UE}

Wielojęzyczność jest jednym z charakterystycznych aspektów systemu prawnego Unii Europejskiej. Ma ona bezprecedensowy i wyjątkowy w skali świata charakter. $\mathrm{Z}$ wielojęzycznością związana jest z kolei zasada jednakowej autentyczności wszystkich wersji językowych, która w odniesieniu do Traktatu o Unii Europejskiej wyrażona została w jego art. 55. Przepis ten wprost stwierdza, że teksty $\mathrm{w}$ każdym $\mathrm{z}$ języków są na równi autentyczne. W stosunku do aktów prawa wtórnego taką rolę pełni rozporządzenie Rady $\mathrm{nr} 1 \mathrm{z}$ dnia 15 kwietnia 1958 r. w sprawie określenia systemu językowego Europejskiej Wspólnoty Gospodarczej³, w którym wymienione zostały wszystkie języki urzędowe Unii i które stanowi, że w językach urzędowych sporządza się rozporządzenia i inne dokumenty powszechnie obowiązujące, oraz publikuje się Dziennik Urzędowy Unii Europejskiej. Chociaż rozporządzenie - w odróżnieniu od art. 55 TUE - nie odnosi się bezpośrednio do zasady jednakowej autentyczności wszystkich wersji językowych, nie wprowadza jednak hierarchii języków urzędowych, ani też jakiegokolwiek uprzywilejowania któregoś z języków bądź ich grupy. Można $\mathrm{z}$ tego wywieść zasadę, że wszystkie wersje językowe aktów prawa UE są jednakowo autentyczne, mają taką samą moc wiążącą i wywołują takie same skutki prawne. Takie spojrzenie na wzajemne relacje między poszczególnymi wersjami językowymi prezentowane jest w orzecznictwie TSUE, który w wyroku CILFIT stwierdził, że akty prawa wspólnotowego sa redagowane $w$ wielu językach $i$ że różne wersje językowe sa na równi autentyczne; wykładnia przepisu prawa wspólnotowego wymaga zatem porównania poszczególnych wersji językowych ${ }^{4}$. Zgodnie $\mathrm{z}$ utrwalonym orzecznictwem Trybunału, różne wersje językowe aktu prawa Unii, należy interpretować w sposób jednolity i wobec tego, w przypadku różnic między tymi wersjami, dany przepis należy interpretować na podstawie ogólnej systematyki i celu regulacji, której część on stanowi ${ }^{5}$.

Z wielojęzycznością systemu prawa UE wiąże się zatem w sposób immanentny zasada jednakowej autentyczności wszystkich wersji językowych. Zasadę tę musi uwzględniać sąd krajowy przy podejmowaniu decyzji o wystąpieniu przez sąd z pytaniem prejudycjalnym.

3 Dz. U. 17 z 6.10.1958 r.; Polskie wydanie specjalne: Rozdział 1, Tom 1, s. 3. Rozporządzenie to podlega zmianom wraz z przyjmowaniem nowych państw członkowskich.

4 Wyrok z dnia 6 października 1982 r., CILFIT i in. (283/81, EU:C1982:335, pkt 18).

5 M.in. wyrok z dnia 29 kwietnia 2010 r., M i in. (C-340/08, EU:C:2010:232, pkt 44) i wyrok z dnia 12 maja 2011 r., Berliner Verkehrsbetriebe (C-144/10, EU:C:2011:300, pkt 28). 


\section{Niespójność pomiędzy poszczególnymi wersjami językowymi}

Jak trafnie zauważa A. Doczekalska, zapewnienie pewności prawa i tworzenie go w sposób jasny i zrozumiały dla adresatów stanowi wyzwanie nawet $\mathrm{w}$ przypadku stanowienia prawa $\mathrm{w}$ jednym języku, a im więcej języków, tym trudniejsze zadanie stoi przed prawodawcą ${ }^{6}$.

Analizując potencjalne źródła niespójności pomiędzy poszczególnymi wersjami językowymi należy na wstępie poczynić zastrzeżenie, że aczkolwiek wszystkie te wersje posiadają przymiot jednakowej autentyczności, to - co oczywiste ze względów praktycznych - tekst prawny nie powstaje we wszystkich tych językach. Większość wersji językowych jest zatem efektem tłumaczenia $\mathrm{z}$ języka, w którym tekst prawny został pierwotnie zredagowany. Językami roboczymi Komisji Europejskiej są: angielski, francuski i niemiecki. Te trzy języki pełnią też rolę tzw. języków pivot ${ }^{7}$ w Parlamencie Europejskim ${ }^{8}$, większość poprawek zgłaszanych przez europarlamentarzystów przygotowywana jest w języku angielskim, a następnie tłumaczona na pozostałe języki ${ }^{9}$. W ten sposób stopien „oryginalności” poszczególnych wersji językowych jest zróżnicowany - w niektórych językach tekst prawny powstaje "na żywo", na niektóre jest tłumaczony w toku samej procedury prawodawczej, a w jeszcze innych przypadkach, gdy dochodzi do rozszerzenia Unii o kolejne państwa członkowskie, mamy do czynienia z klasycznym przekładem prawniczym tekstu prawnego na kolejne języki urzędowe. Pomimo tego zróżnicowania, podkreślić należy, że chronologiczny porządek powstawania wersji językowych nie wpływa w żaden sposób na ich moc i nie podważa zasady ich jednolitej autentyczności.

Proces tłumaczenia prawniczego, bez względu na to, w jakim momencie to tłumaczenie się odbywa, wymaga zrozumienia normy prawnej, a następnie odtworzenia jej (zakodowania) w tłumaczonym na inny język przepisie. W toku tego procesu nastąpić musi odzwierciedlenie w kilkudziesięciu językach pojęć i określeń, które mogą nie posiadać swoich ekwiwalentów, wystąpić mogą również pojęcia synonimiczne, różniące się jednak pod względem znaczeniowym w poszczególnych systemach prawnych. W sposób nieunikniony prowadzi to w praktyce do występowania rozbieżności

6 Zob. A. Doczekalska, Legal multilingualism as a right to remain unilingual - fiction or reality?, „Comparative Legilinguistics” 2014, nr 20.

7 Czyli takich, które pełnią rolę języków pośredniczących np. tłumaczenie z języka estońskiego na polski nie odbywa się bezpośrednio, lecz za pośrednictwem któregoś z języków pivot, na który jest tłumaczony dokument oryginalny, a wersja w języku pivot stanowi następnie podstawę do dalszych tłumaczeń.

8 W Trybunale Sprawiedliwości jako języków pivot używa się francuskiego, angielskiego, niemieckiego, hiszpańskiego i włoskiego.

9 Szerzej o stosowaniu poszczególnych języków urzędowych UE w praktyce redagowania aktów prawa UE zob. A. Doczekalska, Język prawny w tworzeniu i transpozycji prawa Unii Europejskiej, Warszawa 2021, s. 93-104. 
o charakterze lingwistycznym pomiędzy poszczególnymi wersjami językowymi i wynikających z tych rozbieżności problemów interpretacyjnych, które muszą zostać przezwyciężone poprzez sięgnięcie do reguł wykładni systemowej i celowościowej.

Wystąpienie rozbieżności znaczeniowych pomiędzy poszczególnymi wersjami językowymi implikuje konieczność dokonania porównania obejmującego, jak to wynika z orzecznictwa TSUE wszystkie istniejące oficjalne wersje językowe. Takie stanowisko zajął Trybunał odpowiadając na pytanie prejudycjalne w sprawie C-498/03, stwierdzając, że konieczność jednolitej wykładni dyrektyw wspólnotowych wyklucza rozpatrywanie, w razie wątpliwości, danego przepisu w sposób oderwany, lecz przeciwnie - wymaga, aby był on interpretowany i stosowany w świetle jego wersji istniejących w innych językach urzędowych, i że wykładnia musi być dokonana $\mathrm{z}$ uwzględnieniem wszystkich wersji językowych ${ }^{10}$. Z kolei rzecznik generalny $\mathrm{w}$ opinii $\mathrm{w}$ sprawie C-310/04 stwierdził, że Trybunał $w$ przeszłości dawał pierwszeństwo wersjom językowym tworzacym większość, gdy wynikająca $z$ nich wykładnia pozostawała blizsza zamierzonym celom rozporządzenia ${ }^{11}$. W celu ustalenia „większości” w ramach zamkniętego zbioru wersji językowych konieczne jest przeprowadzenie porównania wszystkich istniejących wersji. Niemniej jednak w praktyce Trybunał Sprawiedliwości nie zawsze uwzględnia wszystkie wersje językowe danego przepisu ${ }^{12}$.

Wymóg uwzględniania wszystkich wersji językowych został złagodzony w stosunku do sądów krajowych, co jest uzasadnione ograniczonymi możliwościami i środkami, jakimi te sądy dysponują, w odróżnieniu od Trybunału Sprawiedliwości posiadającego zaplecze techniczne i personalne mogące zapewnić przeprowadzenie potrzebnych analiz językowych. Jak stwierdził rzecznik generalny w opinii z dnia 12 kwietnia 2005 r. przedstawionej w sprawie C-495/03 (pkt 99) - wyroku w sprawie CILFIT nie należy rozumieć $w$ ten sposób, iż sąd krajowy jest na przykład zobowiązany do badania przepisu prawa wspólnotowego w każdym z oficjalnych języków Wspólnoty. Nakładałoby to na sądy krajowe praktycznie niemożliwy do wypetnienia obowiazek [...].

10 Wyrok z dnia 26 maja 2005 r., Kingscrest Associates Ltd, C-498/03(EU:C:2005: 322 , pkt 26 i 27$)$.

11 Opinia rzecznika generalnego E. Sharpston z dnia 16 marca 2006 r. w sprawie C-310/04, pkt 45. Poczynione zastrzeżenie ( $g d y$ wynikajaca $z$ nich wykładnia pozostawała bliższa zamierzonym celom rozporzadzenia) jest istotne, gdyż żadnego języka nie można „przegłosować” w kontekście wykładni - zob. opinię rzecznika generalnego z dnia 12 grudnia 2017 r. w sprawie C-16/16, pkt 140.

12 Zob. K. Paluszek, The equal authenticity of official language versions of European legislation in light of their consideration by the Court of Justice of the European Union, „Comparative Legilinguistics” 2014, nr 18. Z przeprowadzonej analizy ilościowej wynika, że z 80 badanych spraw tylko w 19 przypadkach Trybunał Sprawiedliwości uwzględnił wszystkie wersje językowe. 


\section{Uwzględnianie różnych wersji językowych przez sądy krajowe a prawo do jednojęzyczności}

Wielojęzyczność systemu prawnego UE stanowi w pewnym sensie gwarancję prawa do jednojęzyczności - każdy obywatel państwa członkowskiego ma prawo do posługiwania się tylko swoim językiem ojczystym, a z realizacją tego prawa związany jest obowiązek publikacji aktów prawa UE we wszystkich językach urzędowych. W wyroku w sprawie Skoma-Lux ${ }^{13}$, TSUE orzekł, że pewność prawa wymaga, aby dane przepisy wspólnotowe umożliwiały zainteresowanym osobom dokładne zapoznanie się z zakresem obowiązków, które na nie nakładaja, co jest zagwarantowane wyłacznie poprzez prawidłowa publikację rzeczonych przepisów w języku urzędowym adresata. W konkluzji Trybunał uznał, że na podstawie przepisu prawa UE, który nie został opublikowany w języku urzędowym danego państwa członkowskiego (będącym jednocześnie językiem urzędowym UE), nie można nałożyć obowiązków na jednostki w tym państwie.

$\mathrm{W}$ idealnych warunkach, zasada jednakowej autentyczności wszystkich wersji językowych oraz obowiązek publikacji prawa UE, we wszystkich językach urzędowych powinny zapewnić adresatom i organom stosującym prawo, możliwość stosowania tylko jednej wersji językowej, odpowiadającej ich językowi ojczystemu (językowi urzędowemu danego państwa członkowskiego). W rzeczywistości, ze wskazanych wyżej względów, nie mamy do czynienia $\mathrm{z}$ warunkami idealnymi i w przypadku wystąpienia rozbieżności pomiędzy poszczególnymi wersjami językowymi należy, zgodnie ze wskazówkami TSUE, sięgnąć do wykładni systemowej i teleologicznej.

Nie oznacza to jednak, że obywatel (jednostka) nie ma prawa czerpać swojej wiedzy o prawie z jednej tylko wersji językowej danego aktu. Ponieważ zasada jednakowej autentyczności oznacza formalną ekwiwalencję poszczególnych wersji, nie można z procesu wykładni wykluczyć żadnej z nich.

Sytuacja taka była przedmiotem rozważań Naczelnego Sądu Administracyjnego w wyroku z dnia 23 kwietnia 2008 r. w sprawie o sygn. II GSK $31 / 08$, w której to zastosowanie miały przepisy rozporządzenia Rady (EWG) $\mathrm{Nr} 3821 / 85$ z dnia 20 grudnia 1985 r. w sprawie urządzeń rejestrujących stosowanych $\mathrm{w}$ transporcie drogowym ${ }^{14}$. Przepis art. 4 pkt 3 tego rozporządzenia w polskiej wersji językowej stanowił, że nie ma ono zastosowania do przewozów dokonywanych pojazdami przeznaczonymi do przewozu osób wykonywanego $w$ ramach uslug regularnych, których droga przebiegu przekracza $50 \mathrm{~km}$. Tymczasem w angielskiej wersji językowej użyto sformułowania does not exceed 50 kilometers, które należałoby tłumaczyć jako „nie

13 Wyrok z dnia 11 grudnia 2007 r., Skoma-Lux, C-161/06 (EU:C:2007:773, pkt 38).

14 Dz. U. 1985, L 370, s. 8. 
przekracza 50 kilometrów”. Rozpatrujący sprawę w I instancji Wojewódzki Sąd Administracyjny nie miał wątpliwości, że polska wersja omawianego przepisu była „wadliwa”, a ocenę tę - jak wynika z uzasadnienia wyroku zdawał się podzielać również NSA. W uzasadnieniu wyroku NSA powołał się na orzecznictwo TSUE wskazując, że zgodnie $z$ utrwalonym orzecznictwem ETS spośród kilku możliwych interpretacji przepisu prawa wspólnotowego pierwszeństwo należy dać wykładni zapewniającej jego skuteczność oraz że konieczność jednolitej wykładni prawa wspólnotowego nie pozwala $w$ razie wątpliwości na interpretację brzmienia przepisu $w$ oderwaniu, lecz przeciwnie - wymaga dokonywania jego wykładni w świetle wersji w pozostałych językach urzędowych. NSA nie ograniczył się jednak do powołania zasady jednolitej wykładni prawa UE i obowiązku uwzględniania wszystkich wersji językowych, lecz zwrócił również uwagę na przysługujące jednostce „prawo do jednojęzyczności”. NSA podkreślił, że strona ma prawo oczekiwać rozstrzygnięcia sprawy na podstawie aktu prawnego ogłoszonego w jej własnym języku wraz z przysługujacymi jej uprawnieniami lub nałożonymi obowiazkami, które maja być dla niej wiążace, a brak tłumaczenia lub nieprawidłowe tłumaczenie nie może prowadzić do pogorszenia sytuacji adresatów [...] przepisu. Z rozważań tych można wysnuć wniosek, że NSA uznał konieczność przestrzegania zasady jednolitej wykładni prawa UE i dokonywania jej w oparciu o wszystkie wersje językowe, przy zachowaniu prawa jednostki do posługiwania się i stosowania przepisów opublikowanych w jej języku ojczystym. Należy jednak zaznaczyć, iż z ustalonego w tej konkretnej sprawie stanu faktycznego wynikało, że skarżący nie powoływał się na okoliczność, iż uchybił swoim obowiązkom działając w zaufaniu do przepisu ogłoszonego w polskiej wersji językowej.

W świetle orzecznictwa TSUE, sięgnięcie do różnych wersji językowych danego przepisu, w przypadku problemów interpretacyjnych wydaje się więc oczywiste, sąd musi jednak uwzględniać prawo do jednojęzyczności i wynikające $z$ niego uprawnienia jednostki oraz zasadę zaufania do prawa i pewności prawa. Poniżej przedstawione zostaną przypadki, w których sądy, w wyniku pojawienia się problemów interpretacyjnych na tle różnic w poszczególnych wersjach językowych przepisów zdecydowały się przedłożyć pytania prejudycjalne Trybunałowi Sprawiedliwości.

\section{Sposób wyboru materiału do badań}

W celu zidentyfikowania spraw, w których niespójności pomiędzy wersjami językowymi aktów prawa UE w praktyce stanowiły podstawę do wystąpienia $\mathrm{z}$ wnioskiem o wydanie orzeczenia w trybie prejudycjalnym, zostało wykonane zapytanie za pośrednictwem oficjalnej wyszukiwarki na stronie Trybunału Sprawiedliwości pod kątem występowania wyrażenia (w różnej liczbie i przypadku) „wersja językowa”. Zebrany materiał pozwolił na wyodrębnienie szeregu spraw, w których różnice w poszczególnych wersjach 
językowych były brane pod uwagę na różnych etapach postępowania przed TSUE $^{15}$, a z tak zebranego materiału wybrane zostały dwa wnioski o wydanie orzeczenia $w$ trybie prejudycjalnym, w których potencjalne niespójności terminologiczne pomiędzy poszczególnymi wersjami językowymi stanowiły podstawę wątpliwości interpretacyjnych sądów krajowych, a co za tym idzie główny powód przedstawienia pytań prejudycjalnych.

\section{Odesłanie prejudycjalne w sprawie C-143/20}

Pytanie zostało przedstawione TSUE przez Sąd Rejonowy dla Warszawy Woli postanowieniem z dnia 24 marca 2020 r. (sygn. akt II C 3247/18) w oparciu o następujący stan faktyczny.

Powód będący konsumentem podpisał deklarację przystąpienia do umowy grupowego ubezpieczenia na życie i dożycie z ubezpieczeniowym funduszem kapitałowym. Powód miał być objęty ochroną przez 15 lat.

Zakład ubezpieczeń zobowiązał się do wypłaty świadczeń w przypadku zgonu powoda lub dożycia przez powoda do końca okresu odpowiedzialności. Celem umowy miało być gromadzenie i inwestowanie środków finansowych ubezpieczonego przy wykorzystaniu wydzielonego ubezpieczeniowego funduszu kapitałowego. Fundusz ten powstawał z wpłacanych przez powoda składek. Celem funduszu było powiększanie wartości jego aktywów w wyniku wzrostu wartości jego lokat i ochrona składki zainwestowanej na koniec okresu odpowiedzialności, przy czym ubezpieczyciel nie gwarantował osiągnięcia tego celu. Środki ubezpieczeniowego funduszu kapitałowego lokowane były w całości w wyceniane w polskich złotych certyfikaty, co do których informowano w Regulaminie Funduszu, że inwestycja wiąże się z ryzykiem kredytowym emitenta. Przez to ryzyko rozumiano możliwość wystąpienia trwałej lub czasowej niezdolności emitenta do obsługi zadłużenia, w tym do wykupu wyemitowanych certyfikatów.

Wartość rachunku po zakończeniu okresu odpowiedzialności miała zostać obliczona w oparciu o wartość certyfikatów. Na zakończenie okresu

15 Np. w sprawie C-688/17 zainicjowanej przez sąd węgierski, w której przedmiotem rozważań były angielska, niemiecka i francuska wersja językowa dyrektywy 2004/48/WE Parlamentu Europejskiego i Rady z dnia 29 kwietnia 2004 r. w sprawie egzekwowania praw własności intelektualnej, a w szczególności użyte w niej pojęcie „odszkodowanie" (pkt 23 streszczenia wniosku o wydanie orzeczenia w trybie prejudycjalnym), w sprawie C-103/17, w której analizowano szereg wersji językowych art. 1 ust. 2 dyrektywy Rady 2008/118/WE z dnia 16 grudnia 2008 r. w sprawie ogólnych zasad dotyczących podatku akcyzowego, uchylająca dyrektywę 92/12/EWG (pkt 46 opinii rzecznika generalnego) oraz w sprawie C-100/18 (odesłanie prejudycjalne przedłożone przez sąd hiszpański), w której analizie poddano pojęcie „ruch pojazdów” w różnych wersjach językowych dyrektywy Parlamentu Europejskiego i Rady 2009/103/WE z dnia 16 września 2009 r. w sprawie ubezpieczenia od odpowiedzialności cywilnej za szkody powstałe w związku z ruchem pojazdów mechanicznych i egzekwowania obowiązku ubezpieczania od takiej odpowiedzialności. 
odpowiedzialności, certyfikaty zapewniały ochronę wartości nominalnej, odpowiadającej składce zainwestowanej na dzień zakończenia okresu umowy.

Po upływie 15 lat trwania umowy, powód miał otrzymać świadczenie $\mathrm{w}$ wysokości wartości rachunku w dacie umorzenia, wartość ta miała zostać określona na podstawie regulaminu, i miała wynieść nie mniej niż kwotę odpowiadającą składce zainwestowanej, powiększoną o ewentualną pozytywną zmianę indeksu. Sposób obliczania wartości indeksu nie został nigdzie w umowie określony.

Powód miał również prawo rozwiązać umowę przed upływem 15-letniego okresu, i w takim wypadku pozwany zobowiązał się do dokonania całkowitego wykupu. Ubezpieczyciel miał zwrócić ubezpieczonemu kwotę równą wartości rachunku pomniejszoną o opłatę likwidacyjną (wysokość opłaty likwidacyjnej malała w kolejnych latach obowiązywania umowy).

Wartość jednostki uczestnictwa funduszu obliczano w ten sposób, że dzielono wartość aktywów netto całego funduszu przez liczbę wszystkich jednostek funduszu. W umowie nie określono zasad, według których wyceniane były aktywa netto całego funduszu, nie określono też zasad wyceny certyfikatów, w które środki funduszu miały być lokowane.

Po ponad 7 latach obowiązywania umowy, została ona przez powoda wypowiedziana. $Z$ wpłaconych w tym okresie składek w wysokości 14420 zł, powodowi została wypłacona kwota 7 236,54 zł (opłata likwidacyjna wyniosła 1809,13 zł, a wartość rachunku przed jej potrąceniem wynosiła $9045,67 \mathrm{zl})$.

Powód uważa, że padł ofiarą tzw. misselingu (oferowanie usług finansowych nie odpowiadających potrzebom konsumenta), zjawiska zaliczanego do nieuczciwych praktyk rynkowych. Powód twierdzi, że uzyskał od pozwanego zakładu ubezpieczeń zapewnienie, że wpłacane środki będą blokowane na specjalnym rachunku ubezpieczyciela będącym odpowiednikiem lokaty bankowej.

$\mathrm{Na}$ podstawie dowodów z dokumentów, sąd odsyłający ustalił zakres informacji, jakie zostały przez pozwany zakład ubezpieczeń udzielone powodowi. Sąd stwierdził również, że zakres obowiązku informacyjnego pozwanego ustalić należy z zastosowaniem przepisów prawa UE, a mianowicie dyrektywy 2009/138/WE z dnia 25 listopada 2009 r. w sprawie podejmowania i prowadzenia działalności ubezpieczeniowej i reasekuracyjnej (Wypłacalność II) ${ }^{16}$ oraz dyrektywy 2002/83/WE Parlamentu Europejskiego i Rady z dnia 5 listopada 2002 r. dotyczącej ubezpieczeń na życie ${ }^{17}$. Sąd zaznaczył przy tym, że aczkolwiek ustawa o działalności ubezpieczeniowej z dnia 22 maja 2003 r. ${ }^{18}$ dokonała transpozycji obu dyrektyw do polskiego

16 Dz. U. 2009, L 335, s. 1.

17 Dz. U. 2002, L 345, s. 1.

18 Dz. U. z 2021 r. poz. 1130. 
porządku prawnego, to dokonanie prounijnej wykładni jej przepisów wymaga sięgnięcia do tych dyrektyw. Analizując treść tych dyrektyw, sąd odsyłający powziął wątpliwość w zakresie wykładni przepisów art. 185 ust. 3 lit. i dyrektywy 2009/138/WE oraz art. 36 ust. $1 \mathrm{w}$ zw. z załącznikiem 3 A. pkt 12 dyrektywy 2002/83/WE. W ocenie sądu odsyłającego tekst polskich wersji językowych wskazanych przepisów dyrektyw ma odmienne znaczenie od tłumaczen ${ }^{19}$ tekstów wersji przepisów w językach angielskim, niemieckim i francuskim.

Artykuł 185 dyrektywy 2009/138/WE określa zakres informacji, jakie należy przekazać ubezpieczającemu przed zawarciem umowy ubezpieczenia na życie. Polska wersja językowa przepisu art. 185 ust. 3 lit. i, ma następujące brzmienie:

„i) wskazanie rodzaju podstawowych aktywów dla ubezpieczeń związanych z funduszem inwestycyjnym".

Wątpliwości sądu odsyłającego wzbudziło sformułowanie „wskazanie rodzaju podstawowych aktywów", które to sformułowanie w innych rozpatrywanych przez sąd wersjach językowych brzmi następująco:

„indication of the nature of the underlying assets” - wersja angielska

"Angabe der Art der den fondsgebundenen” - wersja niemiecka

„indications sur la nature des actifs” - wersja francuska

Podobnie w przywołanym przez sąd odsyłający Załączniku III A pkt 12 dyrektywy 2002/83/WE w polskiej wersji językowej użyto sformułowania „wskazanie rodzaju podstawowych aktywów” a w poszczególnych, wymienionych wyżej, wersjach językowych jako ekwiwalent określenia „wskazanie rodzaju” użyto odpowiednio sformułowan "indication of the nature”, „Angabe der Art” i ,indications sur la nature”.

Zdaniem sądu odsyłającego, różnica znaczeniowa pomiędzy polską a wskazanymi wyżej wersjami językowymi jest istotna, gdyż polska wersja językowa nakłada na ubezpieczyciela oraz sprzedającego takie ubezpieczenie, węższy obowiązek informacyjny niż wersja angielska, niemiecka i francuska. Polska wersja - według sądu odsyłającego - przewiduje jedynie obowiązek „wskazania rodzaju podstawowych aktywów”, zaś wersje angielska, niemiecka, francuska - obowiązek przekazywania informacji o naturze, specyfikacji typu, charakterystyki instrumentów bazowych. Sąd odsyłający zauważa, że w kontekście ustalonego stanu faktycznego, gdyby przyjąć, że polska wersja językowa jest prawidłowa, to w konsekwencji należałoby stwierdzić, że pozwany spełnił wymóg „wskazania rodzaju podstawowych aktywów". Sąd skłania się jednak ku takiej wykładni przepisów dyrektywy, która - zdaniem sądu - w innych wersjach językowych przyznaje konsumentowi wyższy standard ochrony. Sąd jednak ma wątpliwości, czy taki

19 W uzasadnieniu postanowienia odsyłającego sąd posłużył się sformułowaniem „tłumaczeń tekstów”, co nie jest, w świetle zamieszczonych wyżej rozważań, określeniem precyzyjnym - należałoby w takich wypadkach mówić raczej o „wersjach językowych". 
wyższy standard ochrony może konsumentowi przyznać, dlatego też postanowił zwrócić się do Trybunału z pytaniami prejudycjalnymi.

Sprawa ta obecnie jest w toku - w dniu 2 września 2021 r. została przedstawiona opinia rzecznika generalnego. W punkcie 99 rzecznik generalny podkreślił, że żadne różnice znaczeniowe występujące w polskiej wersji językowej pkt A ppkt a)11 załacznika III nie zmieniaja zakresu informacji, jakie należy przekazać zgodnie z tym załacznikiem. Z utrwalonego orzecznictwa Trybunału, w sposób oczywisty wynika, że sformułowania użytego w jednej $z$ wersji językowych przepisu prawa Unii nie można traktować jako jedynej podstawy jego wykładni, ani też nie można przyznawać mu w tym zakresie pierwszeństwa względem innych wersji językowych. Konieczność jednolitej wykładni aktu Unii wyklucza jego rozpatrywanie $w$ jednej, w oderwaniu od innych, wersji językowej, natomiast wymaga interpretacji z uwzględnieniem ogólnej systematyki i celu uregulowania, którego przepis ten stanowi część.

\section{Odesłanie prejudycjalne w sprawie (-81/19}

W sprawie C-81/19 mamy do czynienia zarówno z niejednolitym tłumaczeniem wyroku TSUE, jak i przepisów dyrektywy. Sprawa ta dotyczy problematyki kredytów denominowanych w walucie obcej, a wniosek o wydanie orzeczenia w trybie prejudycjalnym został przedstawiony przez sąd apelacyjny w Klużu, w Rumunii, w oparciu o następujący stan faktyczny.

Pozwany SC Volksbank România SA w dniu 15 października 2008 r. udzielił kredytu denominowanego we frankach szwajcarskich (CHF), wypłaconego jednak w walucie rumuńskiej - leju (RON). Ze względu na znaczny wzrost kursu franka szwajcarskiego względem leja, kredytobiorcy w dniu 23 marca 2017 r. wnieśli pozew do wyspecjalizowanego sądu w Klużu (Tribunal Specializat Cluj) wnosząc o zablokowanie kursu wymiany $\mathrm{CHF} / \mathrm{RON}$ na poziomie $\mathrm{z}$ dnia zawarcia umowy oraz o zwrot kwot wypłaconych na podstawie mniej korzystnego kursu wymiany. Kredytobiorcy podnieśli, że bank uchybił ciążącemu na nim obowiązkowi informowania, nie powiadamiając ich w czasie negocjacji i podczas zawarcia umowy, o ryzyku związanym z dewaluacją leja w stosunku do waluty obcej. Zgodnie z wewnętrznym regulaminem banku, dopuszczalny maksymalny pułap zadłużenia wynosił 55\% zdolności finansowej kredytobiorców i został on obliczony z uwzględnieniem kursu wymiany obowiązującego przed podpisaniem umowy kredytowej. Próg ten w stosunku do kredytobiorców w dniu zawarcia umowy wynosił ok. 35\% ich dochodów, natomiast w dalszym okresie, zmiany kursu leja w stosunku do franka spowodowały istotne, dodatkowe koszty po stronie kredytobiorców, gdyż uzyskują oni dochody jedynie w lejach rumuńskich. Zdaniem kredytobiorców bank przeniósł na nich w całości ryzyko wzrostu kursu walutowego. 
Sąd I instancji częściowo uwzględnił powództwo, oddalił jednak żądanie dotyczące stabilizacji kursu wymiany $\mathrm{CHF} / \mathrm{RON}$ obowiązującego $\mathrm{w}$ dniu podpisania umowy kredytu. Obie strony wniosły apelację do sądu apelacyjnego w Klużu (Curtea de Apel Cluj). Sąd ten w toku rozpatrywania sprawy nabrał wątpliwości w przedmiocie możliwości oceny pkt 4 ust. 1 ogólnych warunków umowy kredytu, który stanowił, że wszystkie płatności na jej podstawie są dokonywane w walucie, w której kredyt jest denominowany. Przewidywał on również, że bank jest upoważniony do dokonania wymiany $\mathrm{w}$ imieniu i na rachunek kredytobiorcy w celu wywiązania się z wymagalnych zobowiązań płatniczych przy wykorzystaniu własnego kursu wymiany.

Wątpliwości sądu apelacyjnego zrodziły się $\mathrm{w}$ wyniku porównania dwóch wersji językowych wyroku TSUE z dnia 20 września 2017 r. w sprawie C-186/16, Andriciuc i in. ${ }^{20}$, w szczególności pkt 27 i 28 tego wyroku. W wersji francuskiej, na którą powołuje się sąd odsyłający, użyto w tych punktach, odpowiednio następujących sformułowań:

„dispositions législatives ou réglementaires impératives”

"cette disposition doit être impérative”

Natomiast w wersji rumuńskiej sformułowania te zostały przetłumaczone jako:

"actele cu putere de lege sau normele administrative obligatorii”

„norma respectivă trebuie să fie obligatorie"

Zdaniem sądu odsyłającego pomiędzy tymi sformułowaniami istnieją istotne różnice znaczeniowe, które $\mathrm{w}$ języku polskim ${ }^{21}$ (zgodnie $\mathrm{z}$ polską wersją streszczenia wniosku o wydanie orzeczenia w trybie prejudycjalnym) sprowadzają się do tego, że wersja francuska posługuje się określeniem „bezwzględnie obowiązujące przepisy”, a wersja rumuńska określeniem „normy obligatoryjne" i „obowiązkowe przepisy ustawowe lub wykonawcze". Sąd odsyłający odwołuje się w swoich rozważaniach do znanej również $\mathrm{w}$ polskim systemie prawnym różnicy pomiędzy przepisami bezwzględnie obowiązującymi i względnie obowiązującymi ${ }^{22}$. Sąd zaznacza, że pojęcie „przepisów obowiązkowych”, którym posługuje się rumuńska wersja tłumaczenia wyroku, nie jest tożsame z pojęciem „przepisów bezwzględnie obowiązujących". Zdaniem sądu odsyłającego w przedmiotowej sprawie, rozróżnienie między przepisami bezwzględnie obowiązującymi, a przepisami względnie obowiązującymi nie jest jedynie formalne, lecz dotyczy

20 EU:C:2017:703.

$21 \mathrm{~W}$ polskim tłumaczeniu tego wyroku w pkt 27 użyte jest sformułowanie „bezwzględnie obowiązujące przepisy ustawowe lub wykonawcze”, a w pkt 28 „przepis ten musi być bezwzględnie obowiązujący".

22 Taka terminologia została przyjęta w polskim tłumaczeniu streszczenia wniosku o wydanie orzeczenia w trybie prejudycjalnym, chociaż bardziej precyzyjnie należałoby w tym kontekście mówić o przepisach bezwzględnie (przepisy imperatywne) lub względnie (przepisy dyspozytywne) wiążących. 
istoty sprawy. Otóż kwestionowany przez kredytobiorców pkt 4 ust. 1 ogólnych warunków umowy kredytu, wyraża ustanowioną w art. 1578 obowiązującego w dniu zawarcia umowy rumuńskiego kodeksu cywilnego zasadę nominalizmu, natomiast zgodnie z art. 1 ust. 2 dyrektywy Rady 93/13/EWG z dnia 5 kwietnia $1993 \mathrm{r}$. w sprawie nieuczciwych warunków w umowach konsumenckich ${ }^{23}$ warunki umowy odzwierciedlajace obowiązujace przepisy ustawowe lub wykonawcze [...] nie będa podlegały przepisom niniejszej dyrektywy. Sąd odsyłający zauważa, że wspomniany art. 1578 rumuńskiego kodeksu cywilnego ma charakter względnie obowiązujący ${ }^{24}$, a co za tym idzie - w opinii sądu odsyłającego, który w tym zakresie powołuje się również na niejednolitą praktykę sądów rumuńskich - istnieją poważne wątpliwości, czy mieści się on w zakresie pojęcia obowiązujące przepisy ustawowe lub wykonawcze, którym posługuje się art. 1 ust. 2 dyrektywy 93/13. Uznanie, że art. 1578 nie wchodzi w zakres wyłączenia określonego w art. 1 ust. 2 dyrektywy 93/13, otwierałoby drogę do sądowej kontroli pkt 4 ust. 1 ogólnych warunków umowy kredytu, który to punkt stanowi normatywne odzwierciedlenie wymienionego przepisu rumuńskiego kodeksu cywilnego. W przeciwnym wypadku, jako warunek odzwierciedlający obowiązujące przepisy, nie mógłby on stanowić przedmiotu badania sądu (w zakresie wynikającym z dyrektywy 93/13) w postępowaniu głównym.

W dalszych rozważaniach sąd odsyłający wskazuje, że skutkiem takiej sądowej kontroli inkryminowanego postanowienia ogólnych warunków umowy kredytu, mogłoby być umożliwienie kontynuacji stosunku umownego poprzez spłatę należnych kwot w oparciu o kurs wymiany obowiązujący w dniu podpisania umowy. Jest to, zdaniem sądu odsyłającego, jedyny czas i parametr, na którego podstawie bank dokonał oceny poziomu zadłużenia dłużników i ich zdolności do spłaty rat.

W opinii z dnia 19 marca 2020 r. rzecznik generalna J. Kokott wskazała, że istota sprawy polega na tym, czy warunek zawarty w pkt 4 ust. 1 ogólnych warunków umowy kredytu odzwierciedla zasadę zwaną zasadą „,nominalizmu pieniężnego" przewidzianą w art. 1578 rumuńskiego kodeksu cywilnego i w istocie wynika z przepisów prawa powszechnie obowiązującego, czy też został on narzucony konsumentowi przez bank. Tylko w tym drugim przypadku sąd mógłby badać ewentualnie nieuczciwy charakter tego warunku. Rzecznik generalna zauważa również, że różnice terminologiczne leżące u podstaw problemów interpretacyjnych występują między francuską, a rumuńską wersją dyrektywy 93/13 (sąd odsyłający w postanowieniu odsyłającym nie powoływał się wprost na różnice w wersjach językowych dyrektywy, lecz w tłumaczeniach wyroku w sprawie C-186/16). Nie ulega jednak wątpliwości, że różnice terminologiczne występujące

23 Dz. U. 1993, L 95, s. 29.

24 Czyli, inaczej mówiąc, ma charakter dyspozytywny - strony mogły odstąpić od jego stosowania. 
w tłumaczeniach wyroku mają swoje źródło właśnie w wersjach językowych dyrektywy, która w wersji francuskiej posługuje się określeniem "dispositions législatives ou réglementaires impératives", a w rumuńskiej „norme administrative obligatorii”, które to określenie (w szczególności pojęcie „obligatorii” - „obowiązkowy”) może sugerować, że nie wchodzą w jego zakres przepisy względnie obowiązujące, takie jak art. 1578 rumuńskiego kodeksu cywilnego. Tymczasem w niemieckiej wersji językowej dyrektywy użyto pojęcia „bindend”, które może obejmować przepisy zarówno bezwzględnie, jak i względnie obowiązujące.

Rzecznik generalna nie podzieliła jednak kierunku wykładni, ku któremu skłaniał się sąd odsyłający - odwołując się do wykładni systemowej wskazała, że użyte w dyrektywie pojęcie „obowiązujący” nie odnosi się do tradycyjnego rozróżnienia $\mathrm{w}$ prawie cywilnym między przepisami bezwzględnie wiążącymi ${ }^{25}$ (a więc „obowiązującymi”), a przepisami względnie wiążącymi (a więc „dobrowolnymi”). Rzecznik podniosła, iż zgodnie z zasadą wykładni autonomicznej, pojęcia użyte w dyrektywie 93/13 mają charakter prawa Unii i w związku z tym dla ich wykładni nie jest istotne to, jakie znaczenie ma pojęcie „obligatorii” na gruncie prawa rumuńskiego. W tym kontekście użyty w dyrektywie termin nie powinien być interpretowany w świetle tego, jakie znaczenie przypisuje mu się w rumuńskim (czy też $\mathrm{w}$ jakimkolwiek innym) systemie prawnym, lecz przeciwnie, $\mathrm{w}$ oderwaniu od tego znaczenia ${ }^{26}$. Wobec powyższych rozważań należy przyjąć, że pojęcie użyte $\mathrm{w}$ dyrektywie obejmuje również przepisy o charakterze względnie wiążącym, a co za tym idzie, sporne postanowienie ogólnych warunków umowy kredytu nie podlega sądowej kontroli w zakresie określonym przepisami dyrektywy 93/13.

Opinię tę podzielił Trybunał w wyroku z dnia 9 lipca 2020 r. $^{27}$, który powołując się na wcześniejsze orzecznictwo podkreślił ${ }^{28}$, że sformułowania

25 Warto w tym miejscu zauważyć, że polskie tłumaczenie (z języka niemieckiego) opinii rzecznik generalnej posługuje się pojęciem „wiążące”, gdy tymczasem w polskim tłumaczeniu streszczenia wniosku o wydanie orzeczenia w trybie prejudycjalnym użyto pojęcia „obowiązujące” (językiem oryginalnym wniosku był język rumuński, ale tłumaczenie na polski dokonane było zapewne $\mathrm{z}$ jednego $\mathrm{z}$ tzw. języków pivot). W tłumaczeniach angielskich $\mathrm{z}$ kolei, zarówno w tłumaczeniu opinii rzecznik generalnej, jak i w tłumaczeniu streszczenia wniosku o wydanie orzeczenia w trybie prejudycjalnym, posłużono się jednolicie terminem „mandatory”. W polskim tłumaczeniu wyroku w tej sprawie (np. w pkt 30) ponownie użyto sformułowania „względnie obowiązujące”, gdy tymczasem w angielskim i francuskim tłumaczeniu opinii i wyroku jednolicie używa się terminów odpowiednio „supplementary” i „supplétive” na określenie przepisów względnie wiążących. Przykład ten dobrze ilustruje jak trudne jest utrzymanie jednolitości terminologicznej w obrębie kilkudziesięciu języków i systemów prawnych.

26 Przypomnieć tu należy jeden $\mathrm{z}$ fundamentalnych wyroków TSUE, a mianowicie wyrok z dnia 15 lipca 1964 r., Costa, 6/64, w którego uzasadnieniu Trybunał zawarł stwierdzenie, że Traktat o EWG ustanowił własny system prawny.

27 Dz. U. C 187 z dnia 3 czerwca 2019 r.

28 Zob. pkt 33 wyroku. 
użytego w jednej z wersji językowych przepisu prawa Unii nie można traktować jako jedynej podstawy jego wykładni lub przyznawać mu w tym zakresie pierwszeństwa względem innych wersji językowych. Przepisy prawa Unii należy bowiem interpretować i stosować w sposób jednolity w świetle wersji sporządzonych we wszystkich językach urzędowych Unii. W przypadku wystąpienia rozbieżności między różnymi wersjami językowymi tekstu aktu prawnego Unii lub jeśli pozostają wątpliwości, dany przepis należy interpretować z uwzględnieniem ogólnej systematyki i celu uregulowania, którego stanowi część.

Ponadto, podobnie jak rzecznik generalna, Trybunał odwołał się do wykładni systemowej, wskazując, że w świetle motywu trzynastego ${ }^{29}$ dyrektywy 93/13 przepis art. 1 ust. 2 nie dokonuje żadnego rozróżnienia, z jednej strony pomiędzy przepisami, które mają zastosowanie niezależnie od wyboru umawiających się stron, i z drugiej strony przepisami dyspozytywnymi.

Jak wynika z opisanej wyżej sprawy, wykładnia pojęć użytych w prawie unijnym na podstawie ich znaczenia nadawanego im w systemie prawnym danego państwa członkowskiego, może stać się swoistą pułapką i prowadzić do nieuprawnionych wniosków. Sprawa ta jest również dobrym przykładem wykorzystania wykładni systemowej w celu uzyskania jednolitej normy prawnej w przypadku niezgodności lub niespójności semantycznej różnych wersji językowych tego samego przepisu.

\section{Wnioski}

W odniesieniu do przedstawionych wyżej wniosków o wydanie orzeczenia $\mathrm{w}$ trybie prejudycjalnym poczynić można następujące obserwacje.

W pierwszej kolejności zauważyć należy, iż stanowią one egzemplifikację problemów wykładniczych, jakie rodzą się na gruncie wielojęzyczności systemu prawnego Unii. Niespójność wersji językowych może stanowić źródło wątpliwości interpretacyjnych i skutkować skierowaniem do TSUE wniosku na podstawie art. 267 TFUE. Powstaje jednak pytanie, jakie okoliczności uzasadniają sięgnięcie do innych wersji językowych niż wersja w języku urzędowym danego sądu - zasada jednakowej autentyczności i prawo do jednojęzyczności, zdawałoby się wskazywać, że sięgnięcie do innych wersji językowych powinno nastąpić jedynie wówczas, gdy przepis

29 Zakłada się, iż obowiazujace w państwach członkowskich przepisy ustawowe i wykonawcze, które bezpośrednio lub pośrednio ustalają warunki umów konsumenckich, nie zawieraja nieuczciwych warunków; $w$ związku z tym nie wydaje się konieczne rozpatrywanie warunków umowy, które sa zgodne z obowiązującymi przepisami ustawowymi lub wykonawczymi oraz zgodne z zasadami lub postanowieniami konwencji międzynarodowych, których stronami sa państwa członkowskie lub wspólnota; użyte w art. 1 ust. 2 sformułowanie »obowiazujące przepisy ustawowe lub wykonawcze« obejmuje również zasady, które zgodnie z prawem będa stosowane między umawiającymi się stronami z zastrzeżeniem, że nie dokonano żadnych innych uzgodnień. 
sformułowany w danej wersji językowej jest na tyle niejasny, iż ustalenie jego znaczenia przy zastosowaniu tradycyjnych reguł wykładni jest utrudnione. Takie podejście oznaczałoby, że w sytuacji jasności interpretacyjnej sięganie do innych wersji językowych byłoby zbędne. Wydaje się jednak, iż byłoby to podejście nadmiernie ograniczające. We wniosku skierowanym przez Sąd Rejonowy dla Warszawy - Woli, sąd nie ma wątpliwości co do możliwości poprawnego i jednoznacznego zdekodowania normy prawnej z przepisu, którego dotyczy pytanie prejudycjalne. Wręcz przeciwnie, stwierdza wprost, że polska wersja językowa tego przepisu pozwala na podjęcie określonej decyzji procesowej w postępowaniu głównym (czyli uznanie, że pozwany spełnił swój obowiązek informacyjny). Zdaniem sądu jednak, taki skutek jest niespójny z celami dyrektywy w postaci ochrony interesów konsumentów - sąd zauważa, iż klient nabywał skomplikowany instrument inwestycyjny „opakowany” w umowę grupowego ubezpieczenia na życie i dlatego też powinien mu przysługiwać podwyższony standard ochrony, który - zdaniem sądu - wynika z innych wersji językowych dyrektywy. Można więc przyjąć, że w niektórych przypadkach skorzystanie $\mathrm{z}$ innych wersji językowych można uzasadniać nie tyle niejasnością danego przepisu, co niespójnością o charakterze systemowym i niezgodnością z celami danej regulacji prawa Unii. Sięgnięcie do różnych wersji językowych aktu prawa UE może wynikać więc z konieczności dokonania prounijnej wykładni przepisów krajowych, na którą to okoliczność wprost powołał się Sąd Rejonowy dla Warszawy - Woli.

$\mathrm{W}$ przedstawionych wyżej sprawach, niespójności w tłumaczeniu były zasadniczą przyczyną powstania wątpliwości interpretacyjnych i skierowania $\mathrm{z}$ tego względu pytań prejudycjalnych. W szeregu innych spraw analizowanych w toku przygotowywania niniejszego artykułu często kwestie związane $\mathrm{z}$ wersjami językowymi przepisów pojawiały się natomiast niejako $\mathrm{w}$ tle, na marginesie rozważań zasadniczych. Zwrócić jednak należy uwagę na fakt, iż zazwyczaj sądy odsyłające nie wskazują wprost, jaka okoliczność dała asumpt do sięgnięcia po inną, niż w ich własnym języku urzędowym, wersję językową. Sąd Rejonowy dla Warszawy - Woli wskazał, że sięgnął do dyrektyw implementowanych przez ustawę o działalności ubezpieczeniowej w celu dokonania prawidłowej - „prounijnej” wykładni przepisów krajowych, natomiast sąd rumuński nie wskazał czy posłużenie się inną wersją językową nastąpiło na wniosek którejś ze stron postępowania głównego, czy też było własną inicjatywą sądu.

W kwestii wyboru wersji językowych do porównania, należy przyjąć jak wskazano wyżej - że nie jest zasadne oczekiwanie, by sąd krajowy dokonywał analizy wersji we wszystkich językach urzędowych. Nie oznacza to jednak, że wybór ten może być całkowicie arbitralny. Ze względu na to, że część aktów prawa Unii w istocie była od początku redagowana w określonych wersjach językowych, a część - po kolejnych rozszerzeniach Unii - była $\mathrm{z}$ nich tłumaczona, zasadne byłoby powołanie co najmniej jednej z wersji, 
nie będącej wynikiem tłumaczenia ex post. ${ }^{30}$. Wydaje się również zasadne, aby sąd odsyłający wskazywał z jakiego powodu (na jakich podstawach) wybrał te, a nie inne, wersje językowe do porównania. W przypadku wniosku Sądu Rejonowego dla Warszawy - Woli wydaje się, że sąd wybrał wersje w tzw. językach roboczych (angielski, francuski, niemiecki) natomiast wybór sądu rumuńskiego mógł z jednej strony opierać się na tym, że francuski zwyczajowo jest językiem procedowania w TSUE, z drugiej natomiast na tym, że jest to również język romański i porównanie z rumuńską wersją językową sąd mógł uznać za najbardziej adekwatne. Niemniej jednak żaden z sądów nie wskazał, dlaczego do porównania wybrano te konkretne wersje językowe i dlaczego nie wzięto pod uwagę wersji w innych językach.

Do omówienia pozostaje jeszcze jedna istotna kwestia, a mianowicie językowe kompetencje sądu odsyłającego. Sięgając do wersji językowych w językach innych, niż język w którym toczy się postępowanie, sąd niejako domyślnie uznaje, że posiada należyte kompetencje językowe do wyprowadzenia określonego znaczenia normy prawnej z przepisów sformułowanych w językach obcych. Założenie to może być obarczone pewnym ryzykiem, zwłaszcza że specyfika tłumaczenia prawniczego wymaga ponadprzeciętnej znajomości danego języka. Nawet sytuacje na pozór oczywiste (jak w przypadku wspomnianego wyroku NSA II GSK 31/08: „przekracza” w wersji polskiej i „does not exceed” w wersji angielskiej) mogą okazać się bardziej złożone, jeśli w którejś z wersji językowych zmieniono szyk wyrazów albo zastosowano podwójne przeczenie, inaczej niż w pozostałych wersjach językowych. Tego typu zabiegi, o ile służą oddaniu sensu przepisu, są w tłumaczeniach stosowane i dopuszczalne, a mogą prowadzić do błędnego odczytania znaczenia przez osobę nieposiadającą wystarczającej znajomości danego języka. We wniosku przedłożonym przez Sąd Rejonowy dla Warszawy - Woli, sąd cytując poszczególne wersje językowe stwierdza, że polska wersja przewiduje jedynie obowiązek „wskazania rodzaju podstawowych aktywów”, zaś wersje angielska, niemiecka i francuska nakładają obowiązek „przekazywania informacji o naturze, specyfikacji typu, charakterystyki instrumentów bazowych". Sąd w ten sposób wykonał de facto tłumaczenia tych wersji językowych na język polski (odmiennego od oficjalnej polskiej wersji językowej), nie wskazując jednocześnie argumentów przemawiających za tym, że wersja przedstawiona w odesłaniu prejudycjalnym lepiej oddaje sens tych przepisów, niż oficjalna polska wersja językowa. Formułując odesłanie prejudycjalne, sąd wyszedł zatem z założenia, że 3 wybrane do porównania wersje językowe posiadają inne znaczenie, niż wersja polska. Założenie to wydaje się być ryzykowne, gdy weźmie się pod uwagę, że potencjalna różnica znaczeniowa miałaby dotyczyć dwóch różnych aktów prawnych (dyrektywy 2009/138/WE i dyrektywy 2002/83/

30 Oczywiście takie rozróżnienie ma charakter czysto pragmatyczny i nie oznacza w żadnym wypadku, że „stopień autentyczności” takich aktów tłumaczonych jest mniejszy niż pozostałych. 
WE), które są jednolicie - w zakresie mającym znaczenie dla sprawy - odzwierciedlone w polskich wersjach językowych, to znaczy nie istnieje niespójność w tłumaczeniu tych samych określeń użytych w obu dyrektywach w ich polskich wersjach. Co więcej, gdyby sięgnąć np. do hiszpańskich wersji językowych obu dyrektyw, to użyte w nich określenie „indicaciones sobre la naturaleza" odpowiada użytemu w polskich wersjach językowych wyrażeniu „wskazanie rodzaju” i gdyby tłumaczenie odbywało się w tej parze językowej to nie byłoby podstaw do kwestionowania jego prawidłowości. Nie przesądzając o słuszności (lub nie) tezy zawartej we wniosku Sądu Rejonowego dla Warszawy - Woli zauważyć należy, że ocena nie tyle nawet prawidłowości tłumaczenia, co tożsamości znaczeniowej poszczególnych wersji językowych może przekraczać kompetencje językowe sądu odsyłającego i wymagać wiadomości specjalnych. Ważne jest również to, by określone kompetencje językowe składu sądu odsyłającego nie determinowały wyboru wersji językowych do porównania (potencjalnie taka sytuacja mogła mieć miejsce $\mathrm{w}$ przypadku odesłania prejudycjalnego przedłożonego przez sąd rumuński, który - jak wynika z uzasadnienia postanowienia odsyłającego - również samodzielnie dokonał „przekładu” wersji francuskiej na język rumuński).

\section{Bibliografia}

Biel Ł., Lost in the Eurofog: the textual fit of translated law, Frankfurt 2014.

Doczekalska A., Język prawny w tworzeniu i transpozycji prawa Unii Europejskiej. Procesy hybrydyzacji, Warszawa 2021.

Doczekalska A., Legal multilingualism as a right to remain unilingual - fiction or reality?, „Comparative Legilinguistics” 2014, nr 20.

Miąsik D., Instytucja pytań prejudycjalnych do Trybunału Sprawiedliwości w praktyce Sądu Najwyższego RP, „Ruch Prawniczy, Ekonomiczny i Socjologiczny” 2020, zeszyt 1.

Muszyński M., Pytanie prejudycjalne jako instrument wykładni prawa UE: istota, granice i możliwości kontroli, „Prokuratura i Prawo” 2020, nr 7-8.

Paluszek K., The equal authenticity of official language versions of European legislation in light of their consideration by the Court of Justice of the European Union, „Comparative Legilinguistics" 2014, nr 18.

Sadomski J., Pytania prejudycjalne polskich sadów powszechnych, „Prawo w Działaniu" 2014, nr 20.

Šarćevič S., New Approach to Legal Translation, The Hague-London-Boston 1997.

Szponar-Seroka J., Wielojezzyczność jako wyzwanie w procesie stanowienia i wykładni prawa Unii Europejskiej, „Studenckie Zeszyty Naukowe” 2017, nr 33. 


\section{Niespójność wersji językowych aktu prawa UE}

jako podstawa do wystąpienia z pytaniem prejudycjalnym

\section{Streszczenie}

Wielojęzyczność jest kluczową zasadą funkcjonowania Unii Europejskiej. Zasada jednakowej autentyczności wszystkich wersji językowych prawa UE stanowi istotny element wielojęzyczności. Zasada ta ma charakter formalny, w praktyce mogą pojawić się rozbieżności między poszczególnymi wersjami językowymi. Rozbieżności te mogą skutkować problemami interpretacyjnymi, których rozstrzygnięcie będzie wymagało zainicjowania przez sąd krajowy procedury prejudycjalnej.

Słowa kluczowe: odesłanie prejudycjalne, wielojęzyczność, prawo do jednojęzyczności, język prawny, wykładnia porównawcza

Inconsistency of the Language Versions of an Act of EU Law as a Basis for Making a Preliminary Reference

\section{Abstract}

Multilingualism is a core principle of the European Union's functioning. The principle of equal authenticity of all language versions of the EU law forms part of the essence of the multilingualism. This principle is of a formal nature, in practice divergences between the language versions may become apparent. Said divergences could give rise to interpretative problems, whose solution will require initiating of the preliminary-ruling proceedings by a national court.

Keywords: request for a preliminary ruling, multilingualism, right to unilingualism, legal language, comparative interpretation 